Vol 3, No 1 (2020): Stadium - Hungarian Journal of Sport Sciences

https://doi.org/10.36439/SHJS/2020/1/5430

\title{
A TÁNC ÉS A KOGNITÍV KÉPESSÉGEK KAPCSOLATÁNAK VIZSGÁLATA \\ TÁNC ÉS DEMENCIA
}

\author{
EXAMINATION OF THE RELATIONSHIP BETWEEN DANCE AND COGNITIVE SKILLS \\ DANCE AND DEMENTIA
}

Barna Lilla, Balogh László

Debreceni Egyetem, Sporttudományi Koordinációs Intézet, Debrecen

\section{Összefoglaló}

Bevezetés: A tánc és a kognitív képességek vizsgálata napjainkban elterjedt kutatási téma, illetve számos vizsgálat és cikk található a fizikai aktivitás és a kognitív kapcsolatok aspektusából. A téma vizsgálata elengedhetetlen fontosságú, hiszen a kettő összetevője aktívan befolyásolja teljesítőképességünket és életminőségünket, nemtől, kortól, iskolázottságtól, élethelyzettôl függetlenül.

Célkitüzés: Olyan vizsgálatok kutatása, amely bebizonyítja, hogy a tánc jótékony hatással van a motoros képességekre, a kognitív képességekre. Továbbá a tánc demenciára gyakorolt jótékony kölcsönhatásának kutatása. Olyan mozgásprogramok kutatása, mely az idősödéssel járó folyamatokat nem rontja, vagy gyorsítja, hanem segít a demens állapot akkori stagnálásában.

Módszer: Az elemzéshez angol és magyar nyelven megjelent vizsgálatok áttekintését alkalmazzuk a táncra és a demenciára fókuszálva a Google Scholar és a Research Gate adatbázisokból.

Eredmények: A legtöbb kutatási cikk szerint a különböző táncterápiák hatással vannak a kognitív képességekre, illetve vizsgálatok bizonyítják, hogy a táncos mozgásprogramok (akár párban, akár szólóban) nem rontják a demenciában szenvedő betegek egészségi állapotát. Számos kutatásban nem jelennek meg pontos vizsgálati adatok, melyek rendkívül fontosak lennének a további kutatások függvényében.

Következtetések: Egyrészt a kognitív funkciók és a fizikai aktivitás között szignifikáns kapcsolat figyelhető meg. Másrészt pedig nincsenek konkrét eljárások, mozgásprogramok, mérési módszerek, amelyek által javítható a demens állapot.

Kulcsszavak: fizikai aktivitás, tánc, versenytánc, táncterápia, demencia, review

\begin{abstract}
Introduction: The study of dance and cognitive abilities is a common research topic today, as well as many studies and articles on the aspects of physical activity and cognitive relationships. Studying the topic is essential, as the two components actively influence our performance and quality of life, regardless of gender, age, or education

Objective: To examine the effect of dancing activities has a beneficial effect on motor and cognitive abilities. Furthermore, to investigate the interaction of dance and dementia.

Researching exercise programs that do not worsen or accelerate the processes associated with aging, but help to stagnate dementia at that time.

Method: For analysis, we used an overview of English and Hungarian studies focusing on dance and dementia from Google Scholar and Research Gate.
\end{abstract}

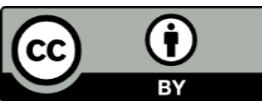


Vol 3, No 1 (2020): Stadium - Hungarian Journal of Sport Sciences

https://doi.org/10.36439/SHJS/2020/1/5430

Results: According to most research articles, various dance therapies have an impact on cognitive abilities, and studies have shown that dancing exercise programs (either in pairs or solo) do not impair the health of people with dementia. Many studies do not provide accurate test data, which would be extremely important as further research is conducted.

Conclusions: First, there is a significant relationship between cognitive function and physical activity. On the other hand, there are no specific procedures, exercise programs, or measurement methods that can improve dementia.

Keywords: physical activity, dance, ballroom dancing, dance therapy, dementia, review 
Vol 3, No 1 (2020): Stadium - Hungarian Journal of Sport Sciences

https://doi.org/10.36439/SHJS/2020/1/5430

\section{ELMÉLETI HÁTTÉR}

Ahogy a Dubecz- féle hagyma ábra is szemlélteti, a sportteljesítményt komplex fogalomként értelmezzük. (RADÁK, 2016) A fizikai teljesítményt négy változó határozza meg. A kondicionális- és koordinációs képességek és az ezeket befolyásoló tényezők, valamint az emocionális- affektív képességek és a kognitív képességek, illetve az ezeket befolyásoló tényezők. Mindezek elengedhetetlen részei a hétköznapi és a versenyhelyzetekben átélt folyamatoknak.

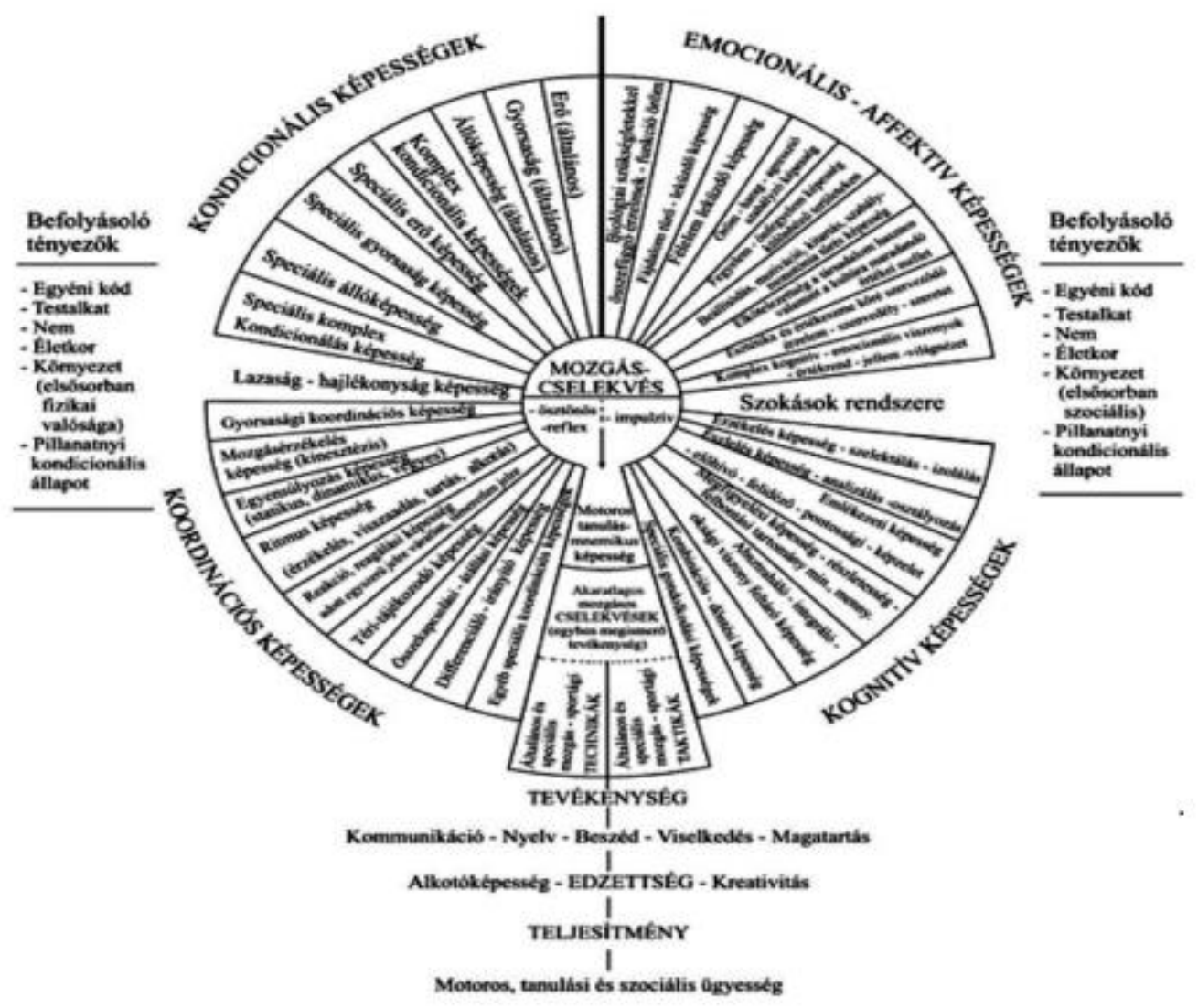

1. ábra: A sportteljesitményt meghatározó összetevök komplex rendszere, A „Dubecz-féle” hagyma Radák, 2016

A szakirodalmi áttekintés során arról szeretnénk tudomást nyerni, miszerint hatással van-e a tánc az egyén kognitív képességeire, ha igen, akkor milyen irányban, illetve, hogy a demenciával együtt élő idősekre befolyással bír-e a tánc vagy a tánc terápia. Mielőtt a tánc és táncterápia témakörét közelebbről vizsgálnánk fontos megjegyezni néhány fogalmat a szakirodalmak szerint.

Az Egészségügyi Világszervezet 1986-os Ottawai konferencián fogalmazta meg, hogy „Az egészség a teljes testi, mentális és szociális jóllét állapota, és nem csupán betegség- vagy fogyatékosság-nélküliség.” A fizikai aktivitás pedig Caspersen et al. (1985) szerint „minden olyan mozgás, amelyet a vázizomzat hoz létre, és energiafelhasználás kísér.” 
A tánc a 2012- es Nemzeti alaptanterv megfogalmazása szerint: „A művészi tevékenységek semmi mással nem pótolható szerepet játszanak a képzelőerő, az empátia, az ízlés és az árnyalt kifejezés képességének fejlesztésében. Kora gyermekkortól kezdve ezek szolgálják a leghathatósabban a forma-, a tér-, a ritmus- és a színérzék kibontakozását, a mozgáskoordináció fejlesztését, és elengedhetetlenek a figyelem, az emlékezet, valamint a kooperációs és kommunikációs készségek fejlesztésében is." (NAT, 2012) „Szoros kölcsönhatásban szabályozza, fejleszti és finomítja a különböző képességeket, mint pl.: a fogékonyság, a fantázia, a koncentráció, a jó értelemben vett érzékenység, az észlelés finomsága, a kifejezés árnyaltságának fejlesztése, valamint az értékek iránti fogékonyság, testi-, térbeli biztonság, idő- és ritmusérzék, ügyesség, megfelelő erőadagolás (NAT, 2012). Ravelin et al. (2011) szerint a tánc kulturálisan megszerzett emberi erőforrás. Kreatív, egyedi ugyanakkor egyetemes. A tánc az egyén testi kifejezését, az érzelmeket és a történeteket az énnel és a másokkal történő interakcióban vetíti ki. A tánc terápiaként történő alkalmazása elősegítheti az ego megértését és a társadalmi interakciókat.

„A dementia az agyi betegség miatt fellépő szindróma, általában krónikus vagy progresszív jellegú, amelyben több magasabb kortikális funkció zavara van, ideértve a memóriát, a gondolkodást, az orientációt, a megértést, a számítást, a nyelvet és az ítéletet" (WHO, 1992).

Tény, hogy idősödés során csökken a szenzomotoros és kognitív, fizikai teljesítmény, ám bizonyított, hogy testmozgás, edzés hatására stagnálhatnak, vagy már- már javulhatnak ezek az életkorral járó változások. Mivel a tánc több kognitív képességre is komplexen hat, így terápiaként rendkívül hatékony módja lehet a demenciában szenvedő idősek kezelésében. (CARCEL et al., 2012; SINGH-MANOUX, 2005, CARVALHO et al., 2014) A tánc a koordinált mozgás mellett fejleszti az egyensúlyérzéket, hatással van az izomrendszer összehangolt múködésére, felhasználja a test erejét, aktivizálja a mozgásutánzó képességet, így hatást gyakorolva a memóriára. Általa művelője képessé válik a differenciált mozgásra, a lassabb és gyorsabb mozdulatok egymás utáni végrehajtására (SÁRI, 1998), illetve mivel folyamatos mozgásban van, még akkor is, ha ez nem tûnik fel, igen jótékony hatással van az egészség hosszabb távú megőrzésében is (VERMES, 1999).

Az időskori demenciával együtt élő emberek speciális támogatást igényelnek, hogy fel tudják dolgozni az idős korhoz kapcsolódó pszichoszociális témákat (ERIKSON et al. 1986). Elsődleges teendő, hogy biztosítva legyen számukra a megfelelő energiaforrás ahhoz, hogy fenntartsák vagy javítsák életminőségüket, ne forduljon elő mentális hanyatlás. A tevékenységek általi azonnali öröm, a méltóság helyreállítása, illetve a barátságok kialakítása fontos alkotórészei lehetnek. A tánc által a mozgás és a zene nagy szerepet játszik a test és az elme kölcsönhatásában. Korábbi kutatások kimutatták, hogy a mûvészet által élményeket és művészeti élvezetet okoz, nyújt az embereknek. Götell, Lepp és Hannemann szerint van összefüggés a jobb életminőség kialakulásában és a művészeti illetve kulturális tevékenységek között. (GÖTELL, 2003; LEPP et al., 2003; HANNEMANN, 2006). Napjainkban körülbelül 24 millió ember szenved demenciában, de különböző becslések szerint 2040-re több, mint kétszeresére növekszik a diagnosztizált 
betegek száma, közel 81 millióra, melynek oka, hogy az emberek egyre hosszabb gazdasági és társadalmi életet élnek. (HARVEY et al., 2016) A fejlett világ számos részében tekinthető nagy problémának, hogy az idősödő társadalom egyre nagyobb része szenved demenciában, szenilitásban és Alzheimer- kórban. Mivel ez egy krónikus és gyógyíthatatlan betegség, elengedhetetlen beszélni a terápiás beavatkozásokról. A gyógyászati megközelítésről számos tanulmány számol be, ám fontos megemlíteni a nem gyógyászati kezeléseket is, melyek hozzájárulnak ahhoz, hogy a betegek életminősége pozitívabb szemléletű legyen. Japánban, több intézetben tánc- és mozgásterápiával kezdeményeznek a betegek jólétének irányába. Úgy gondolják, hogy a táncban alkalmazott emlékezőképesség hatékonyabb, mint a verbális módszerek használata egy pszichoterápia során. (ARAKAWA - DAVIES, 1997)

Tánctanulás során lépések, később összetett koreográfiák kerülnek elsajátításra. A lépések rögzítése közben észrevétlenül lép múködésbe a kinesztetikus tudatosság (ARAKAWA- DAVIES, 1977) „A kinesztetikus (testmozgással kapcsolatos) információk nem minden eleme kelt érzékletet az agyban, vagyis a jelenségek egy része tudattalanul zajlik le. A motoros tanulás során a hatékonyabb előrehaladást ezeknek a tudattalanul lezajló folyamatoknak a tudatosság szintjére emelése biztosítja. „(MAKSZIN, 2014) A téri gondolkodás aktívan működik, mivel minél több lépés kerül elsajátításra, annál jobban aktiválódik a téri elforgatás képessége, nem beszélve ezáltal a kognitív flexibilitásról is. A folyamatosan elsajátított koreográfiak által a táncot végző személyből előtörhetnek korábbi emlékek akár egy mozdulat által, akár érintés, érintkezés által. Előtörhetnek érzelmek, vagy akár szexuális emlékek is felidézhetnek. Ugyanis „az emlékeket a test tárolja." (COATEN, 2001) Lehet, hogy az elmében az idősödés folyamatában felejtés jön létre, ám a test nem felejt, megfelelő mozgásterápiával rengeteg emlék visszahozható, felidézhető. Először is a tánc újjáéleszti a testi mozgásokat, felszabadítja a pszichofizikai feszültségeket és az elszigeteltség érzését. Ösztönzi a konstruktív visszahívást, a valósági kapcsolatokat és a társadalmi interakciót, valamint lehetőséget kínál az érzések kifejezésére. (ARAKAWA- DAVIES, 1997) A kinesztetikus tanulás mellett a másik rendkívül fontos tényező a táncolás során, a zene. A zene által már mozgás nélkül is rendkívül sok emlék felidézőik, a ritmus tehát felébreszti az emlékeket. A zenére történő mozgás közben észrevétlenül megmozdulhatnak a lábak mellett a karok is, amely a végrehajtás közben magabiztosságra, önállóságra adhat okot. Ezáltal a testi kommunikáció is sokkal pozitívabb irányt mutat. Egy számukra kedves dallamra, dalra történő mozgás által kibillen az egyén az aktuálisan befelé forduló hangulatából, ezáltal a memóriájuk ösztönzésre kerülhet. A tánc kreatív folyamata a csoportos munka élménye révén segíti elő a tanulók alkotó és kapcsolatteremtő képességének kibontakozását, összpontosított, megtervezett munkára szoktatását. A tánc speciális művészeti ismereteket nyújt, és az alkotómunkával együtt járó élmények segítségével hozzájárul a gyermekek kreatív személyiségének kialakításához, mozgásának harmóniájához és beszédük tisztaságához, szolgálja ön- és társismeretük gazdagodását. A mozgásos-táncos tevékenységek fejlesztik a zenei képességeket, a térérzékelést, a testtartást, a mozgáskoordinációt, az állóképességet. (NAT, 2012) 


\section{MÓDSZER}

Az elemzéshez túlnyomó részt angol, valamint magyar nyelven megjelent vizsgálatok áttekintését alkalmaztunk a táncra és a kognitív képességek kapcsolatára, valamint táncterápiára és a demenciára fókuszálva a Google Scholar és a Research Gate adatbázisokból.

\section{EREDMÉNYEK}

Kattenstroth et al. 2013-ban megjelent cikkükben arról számoltak be, hogy 6 hónapon keresztül vizsgáltak felnőtt egészséges nőket, akik heti egyszer vettek részt táncórán, összehasonlítva az egyeztetett kontrollcsoportban résztvevőkkel. A részletes felmérést követve (kogníció, intelligencia, figyelem, reakcióidő, motoros, tapintható és testtartó teljesítményről, valamint a szubjektív jólétről és a kardio-légzőképesség) arra jutottak, hogy a tánccsoportban résztvevőknél jelentős változás mérhető leginkább azoknál, akik a képzést megelőző vizsgálatok során a leggyengébb teljesítményt mutatták. Összesen 35 nő bevonásával készült a vizsgálat, a 220 potenciális jelentkező közül, akik korábban nem végeztek semmiféle táncos tevékenységet, nincs semmilyen előképzettségük. A vizsgált csoport egy speciális programban vett részt, 24 héten át heti egyszer. Az óra 20 perc bemelegítéssel kezdődik, amit egy 40 perces táncos rész követ. A kifejlesztett program egyik pozitív jellemzője, hogy egyedül is végrehajtható, nem szükséges hozzá partner, hisz egy 2009-es felmérés szerint Európában a 60 év fölötti nők 73\%-a egyedül él (HAUSTEIN - MISCHKE, 2011). Így nem alakulhat ki gát a partnerhiány okozta nehézségek miatt. Az órákat követően elégedettségi kérdőíveket töltettek ki a résztvevőkkel, akiknek 76\%-a sokkal jobban érezte magát, az izom- és csontrendszert illetően a résztvevők 52\%-a kevesebb fájdalmat tapasztalt, míg a csoport 100\%-a szerint rendkívül jó érzés, hogy valamit egyedül csinálhatnak. 96\% szívesen javasolja másoknak is táncórákon való részvételt, míg 76\%-uk pedig szívesen folytatná. Ezen adatok (2. ábra) tehát jól mutatják, hogy a táncos- zenés terápia pozitív hatással van a személyek szubjektív jólétére és megelégedettségére. (HUI et al. 2008 ; KREUTZ, 2008; HACKNEY - EARHART, 2010).

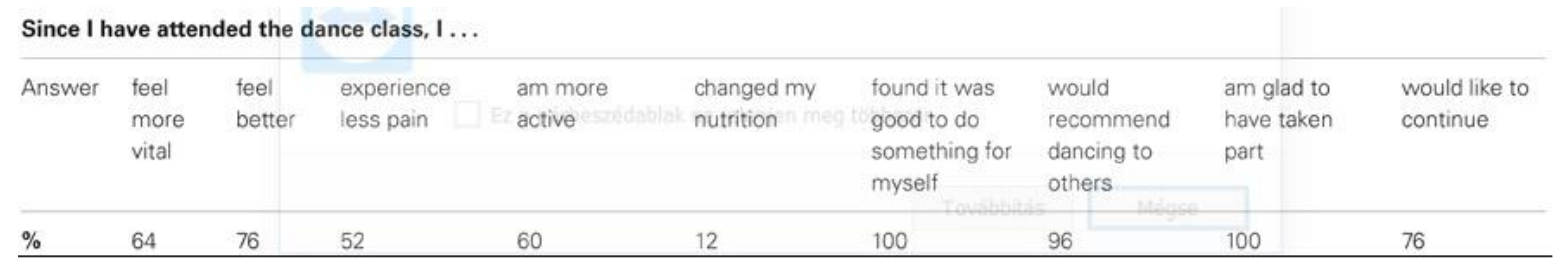

2. ábra: A táncos foglalkozásokon résztvevők véleménye a gyakorlás után

Fülöp-szigeteki kutatók méréseket kezdeményeztek, hogy vajon a társastáncok művelése milyen hatással lesz a memóriára, az új emlékek kialakítására. Véleményük szerint a táncok tanulása és gyakorlása alapvető stratégia lehet a demencia megelőzésében, hiszen aktívan stimulálja a kognitív képességeket, valamint a társadalomba való beilleszkedést is megkönnyíti. Vizsgálatuk során tizenhárom, 60-65 éves, iskolázott embert elemeztek, 
akik egy éven keresztül heti háromszor harminc percet töltöttek tánccal, és hasonlították össze 13 ugyanilyen korú és iskolázottságú emberrel, akik mozgásszegény életmódot folytattak. Bebizonyosodott, hogy sokkal jobb állapotban van a táncot művelők memóriája, mint a kontrollcsoportban résztvevőké. A hippokampusz állapotát tekintve tehát (mely szerepet játszik összetett információk, események memorizálásában) a jobb és bal oldal aktívabban múködik. (CARCEL et. al., 2012.)

Német kutatók aktív, szenior IV. korosztályban (60-94 év) versenyző táncosokat vizsgáltak, összehasonlítva ugyanezen korosztály nem sportoló társaikkal. Végeredményben látható, hogy a kognitív képességekben, az egyensúly tesztekben, valamint a kognitív flexibilitás tekintetében a hasonló korú, nemű és iskolai végzettéggel rendelkező társaikkal szemben a versenyzők kiemelkedő teljesítményt nyújtottak. E vizsgálat rávilágít arra, hogy fiatal korban elkezdett társastánc, majd heti rendszeres táncedzés által tanultak egészen idős korig megőrizhetők. Ám, speciális táncos tudáson kívüli feladatokban hasonló elmaradás figyelhető meg, mint nem táncoló kortársaiknál. (KATTENSTROTH et al., 2013)

A Brit Pszichológiai Társaság egyik vizsgálatában egy ápolási otthonban 22 személyt vizsgáltak, melyből 13 szenvedett demenciában. Első ízben interjúk alapján úgy tapasztalták mind a betegek, mind pedig a segítő személyzet véleménye alapján, hogy a táncórák javítják a pozitív érzelmi állapotaikat, valamint igencsak megemelkedett az általános elégedettségi szintjük is (GUZMÁN -GARCÍA et al., 2012).

Ír kutatók felmérésük alapján bebizonyították, amelyben 39 személyt vizsgáltak ír táncok gyakorlása előtt és után, mini BESTest valamint EuroQol vizuális analóg skála segítségével, hogy a rendszeres táncolás az idősebb felnőttek egészségügyi előnyeivel jár, valamint pozitívan hat az érzelmi jólétre és a kognitív funkcióikra. (SHANAHAN et al., 2016)

Ravelin és mtsai (2011) kutatásukban leírják, hogy a vizsgált 13 demens személyre milyen hatással van 4 különböző idôben és témában feldolgozott táncelőadások megfigyelései. Megfigyelések által megállapították, hogy a tánc különböző formái aktivizálják az idős emberek erőforrásait, pozitív hozzáállást tanúsítottak mind az előadásokkal, mind pedig az előadóművészekkel szemben. Az előadások alatt a vizsgált személyek elfelejtették betegségüket, valamint érzelmeket és emlékképeket idéztek fel.

Lapum és szerző társai (2016) kutatásukban megállapítják, hogy a mozgás és a zene együttesen rendkívül fontos szerepet játszik az emberek életében, nyomot hagy a testre és az elmére egyaránt. A táncos mozgás tehát, szoros kontaktusban van memóriával. A cikkben gondolatokat osztanak meg az olvasókkal, miszerint a demenciára pozitív hatással lehet tánc. Elemzésükben felhasználják az öregedő népességgel kapcsolatos tapasztalataikat, valamit a kanadai Nemzeti Balettiskola és a Baycrest Health Sciences által kidolgozott táncprogramot. (CARCEL et al., 2012) 


\section{MEGBESZÉLÉS}

Hangsúlyozandó, hogy a konkrét kutatási eredmények eléréséhez nélkülözhetetlenek a pontos kutatási adatok felvétele. A fizikai aktivitás csökkenti az idősödéssel járó testi és agyi funkcióinak romlási esélyét. A demenciában szenvedő idősek számára jótékony mozgásforma a tánc és annak különböző zenés/mozgásos változatai. Amellett, hogy végrehajtják a mozgásformát, a táncos előadások is segíthetik a kognitív képességek frissen tartását, az előadások alatt elfelejthetik betegségüket, különböző érzelmeket válthatnak ki belőlük, emlékképeket idézhetnek elő. A jövőre vonatkozóan terveink közt szerepel egy táncos mozgásprogram kidolgozása, amely életkor, és nem szerint pozitív hatással lehet a kognitív képességekre és segíthet a demenciában szenvedő időseknek átérezni a sikeres öregedés életérzését. Valamint a használatos mérési módszerek fejlesztése, újak kifejlesztése, melynek célja ezen színtéren történő fejlesztés.

A publikáció elkészítését az EFOP-3.6.1-16-2016-00022 „Debrecen Venture Catapult Program" projekt támogatta. A projekt az Európai Unió támogatásával, az Európai Szociális Alap társfinanszírozásával valósult meg.

\section{IRODALOMJEGYZÉK}

Arakawa K., Davies M. A. (1997). Dance/movement therapy and reminiscence: A new approach to senile dementia in Japan. The Arts in Psychotherapy, 24, (3), 291-298.

Carcel C., Dasig D., Noble P., Ledesma L., Adapon H., \& Tuason J. (2012). Can ballroom dancing make you smarter? An investigation on its relationship with hippocampal volume and memory performance in older adults. Makati Medical Center, Makati City, Philippines, P1-101.

Carvalho A., Maeve Rea I., Parimon T., \& Cusack B. J. (2014). Physical activity and cognitive function in individuals over 60 years of age: a systematic review. Clin Interv Aging, 9, 661-682.

Caspersen C. J., Powell K. E., \& Christenson G. M. (1985). Physical activity, exercise, and physical fitness: definitions and distinctions for health-related research. Public Health $100,(2), 126-131$.

Coaten R. (2001). Exploring reminiscence through dance and movement. Journal of Dementia Care, 9, (5), 19-22.

Erikson E. H., Erikson J. M., \& Kivnick H. Q. (1986). Vital involvement in old age. New York: W. W. Norton \& Co. 
Götell E., Brown S., \& Ekman S. L. (2003). Influence of Caregiver Singing and Background Music on Posture, Movement, and Sensory Awareness in Dementia Care, International Psychogeriatrics, 15, (4), 411-430.

Guzmán - García A., Mukaetova- Ladinska E., \& James I. (2012). Introducing a Latin ballroom dance class to people with dementia living in care homes, benefits and concerns: A pilot study. Dementia, March, 16.

Hackney M., Earhart G. (2010). Social partnered dance for people with serious and persistent mental illness: a pilot study. J. Nerv. Ment. Dis, 198, 76-78.

Hannemann B. T. (2006). Creativity with dementia patients. Can creativity and art stimulate dementia patients positively? Gerontology, 52, (1), 59-65.

Harvey L., Mitchell R., Brodaty H., Draper B., \& Close J. (2016). Dementia: A risk factor for burns in the elderly. Burns, 42, (2), 282-90.

Haustein T., Mischke J. (2011). Ältere Menschen in Deutschland und der EU, in Im Blickpunkt (Wiesbaden: Statistisches Bundesamt; ).

Hui E., Chui B., \& Woo J. (2008). Effects of dance on physical and psychological well-being in older persons. Arch. Gerontol. Geriatr., 49, e45-e50 10.1016/j.archger.2008.08.006

Kattenstroth, J. C. Kalisch, T. Holt, S. Tegenthoff, M. \& Dinse, H. R. (2013). Six months of dance intervention enhances postural, sensorimotor, and cognitive performance in elderly without affecting cardio-respiratory functions. Frontiers in Aging Neuroscience, 5, 1-16.

Kreutz G. (2008). Does partnered dance promote health? The case of tango Argentino. J. R. Soc. Promot. Health, 128, 79-84.

Lapum J. R., Bar R. J. (2016). Dance for Individuals With Dementia. Journal of Psychosocial Nursing and Mental Health Services, 54, (3), 31-34.

Lepp M., Ringsberg K. C., Holm A. K., \& Sellersjö G. (2003). Dementia - involving patients and their caregivers in a drama programme: the caregivers' experiences, Journal of Clinical Nursing, 12, (6).

Makszin I. (2014). A testnevelés elmélete és módszertana. Dialóg Campus. 
Radák Zs. (2016). A sportteljesítményt meghatározó összetevők komplex rendszere, A „Dubecz-féle” hagyma. Edzésélettan. Krea-Fitt Kft, Budapest. 11-17.

Ravelin T., Isola A., \& Kylma J. (2011). Dance performance as a method of intervention as experienced by older persons with dementia. International Journal of Older People Nursing, 8, (1), 10-18.

Sári J. (1998). A mozgás túlmutat önmagán. Budapest: Új Pedagógiai Szemle.

Shanahan J., Coman L., Ryan F., Saunders J., O'Sullivan K., Ni Bhriain O., \& Clifford A. M. (2016). To dance or not to dance? A comparison of balance, physical fitness and quality of life in older Irish set dancers and age-matched controls. Public Health, 141:56-62. doi: 10.1016/j.puhe.2016.07.015. Epub 2016 Sep 28.

Singh-Manoux A., Hillsdon M, Brunner E, \& Marmot M. (2005). Effects of physical activity on cognitive functioning in middle age: evidence from the Whitehall II prospective cohort study. Am J Public Health. 95, (12), 2252-8.

Vermes K. (1999). A test valósága, mint élménykép kapcsolata In: Pszichoterápia, 15, (6), 425-431. 